Review

\title{
Adverse Events Following COVID-19 Vaccine in Patients Previously Injected with Facial Filler: Scoping Review and Case Report
}

\author{
Raffaele Rauso ${ }^{1}$, Giorgio Lo Giudice ${ }^{2, *}$, , Nicola Zerbinati ${ }^{3}$, Giovanni Francesco Nicoletti ${ }^{4}$, Romolo Fragola ${ }^{1}(\mathbb{D}$ \\ and Gianpaolo Tartaro ${ }^{1}$ \\ 1 Multidisciplinary Department of Medical-Surgical and Dental Specialties, Oral and Maxillofacial Surgery \\ Unit, University of Campania “Luigi Vanvitelli”, Via Luigi De Crecchio 6, 80138 Naples, Italy; \\ raffaele.rauso@unicampania.it (R.R.); romolofragola@gmail.com (R.F.); \\ gianpaolo.tartaro@unicampania.it (G.T.) \\ 2 Department of Neurosciences, Reproductive and Odontostomatological Sciences, Maxillofacial Surgery Unit, \\ University of Naples "Federico II", Via Pansini 5, 80131 Naples, Italy \\ 3 Dermatology Department, University of Insubria, Via Guicciardini 9, 21100 Varese, Italy; \\ nzerbinati@centro-medico.it \\ 4 Multidisciplinary Department of Medical-Surgical and Dental Specialties, Plastic Surgery Unit, \\ University of Campania "Luigi Vanvitelli", Via Luigi De Crecchio 6, 80138 Naples, Italy; \\ giovannifrancesco.nicoletti@unicampania.it \\ * Correspondence: giorgio.logiudice@unina.it
}

check for updates

Citation: Rauso, R.; Lo Giudice, G.; Zerbinati, N.; Nicoletti, G.F.; Fragola, R.; Tartaro, G. Adverse Events Following COVID-19 Vaccine in Patients Previously Injected with Facial Filler: Scoping Review and Case Report. Appl. Sci. 2021, 11, 10888. https://doi.org/10.3390/ app112210888

Academic Editor: Gabi Chaushu

Received: 15 October 2021

Accepted: 15 November 2021

Published: 18 November 2021

Publisher's Note: MDPI stays neutral with regard to jurisdictional claims in published maps and institutional affiliations.

Copyright: (c) 2021 by the authors. Licensee MDPI, Basel, Switzerland. This article is an open access article distributed under the terms and conditions of the Creative Commons Attribution (CC BY) license (https:// creativecommons.org/licenses/by/ $4.0 /)$.

\begin{abstract}
The "Vaccines and Related Biological Products Advisory Committee 17 December 2020 Meeting Briefing Document", formulated by the FDA, reported three cases of swelling in areas previously injected with HA filler, introducing the possible relationship between a COVID-19 vaccine and adverse events in areas previously injected with HA fillers. The aim of this research is to report a case of an adverse event following a COVID-19 vaccine in a patient previously injected with facial filler. Furthermore, a scoping review on the same topic was performed. The research was carried out on the electronic databases PubMed, Cochrane Library, Web of Science, Google Scholar and Scopus. The selection process identified four articles as eligible for inclusion in the review. Nineteen patients, including the described case report, who experienced an adverse event following a COVID-19 vaccine in areas previously injected with facial filler were identified. Adverse events following a COVID-19 vaccine in patients previously injected with facial filler appear to be rare. A high BDDE cross-linking rate and/or a low-molecular-weight hyaluronic acid filler may have a higher tardive adverse event rate when triggered.
\end{abstract}

Keywords: filler; hyaluronic acid; adverse reaction; COVID-19; COVID-19 vaccines; SARS-CoV-2

\section{Introduction}

On 31 December 2019, the Wuhan Municipal Health Commission (China) reported a cluster of pneumonia cases that were induced by a novel coronavirus called SARS-CoV2. Subsequently, this infection spread quickly across the globe in 2020 and by 11 March 2020, the World Health Organization (WHO) had announced that the COVID-19 outbreak was a new pandemic [1]. The COVID-19 pandemic had, and continues to have, a severe impact on healthcare systems worldwide. Every country underwent lockdowns of various durations and applied limitations based on the occupation of the Intensive Care Units (ICU) by COVID-19 infected patients [2-5]. Several doctors moved from their specialist area of practice in order to support ICU patients and those specialist medicinal areas that did not focus on emergency or respiratory illnesses were adjusted to face this new situation [4]. During the COVID-19 outbreak, several specialties modified their care delivery model from conventional (face to face) to virtual or remote care, performed via telemedicine [6-9]. 
The social distancing policies that were introduced during this time led to the widespread adoption of video-calling applications for school, work, and social interaction [10].

Sub-specialities such as aesthetic surgery and aesthetic medicine halted completely. Despite this block, the statistics released by the American Society of Aesthetic Plastic Surgery (ASAPS) reported only a small reduction in surgical procedures performed and an increase in non-surgical aesthetic procedures between 2019 and 2020 [11,12]. Injections of botulinum toxin for aesthetic purposes increased from 1,712,994 procedures performed in 2019 to 2,644,366 in 2020; furthermore, dermal filler injections increased from 812,285 performed in 2019 to 1,313,206 in 2020 [11,12]. Some authors showed that the increased time spent comparing oneself to others while on video calls is associated with a decreased body and face satisfaction $[13,14]$. This may provide an explanation for the recorded increase reported by the ASAPS, especially for facial procedures.

Among dermal filler injections, hyaluronic acid (HA) is the most-used substance due to the wide range of applications developed for its usage in recent years $[15,16]$ and its safety profile, as administration is via an injection and can easily be reversed [17-19]. In 2020, the clinical trial for a COVID-19 vaccine started. The "Vaccines and Related Biological Products Advisory Committee 17 December 2020 Meeting Briefing Document", formulated by the Food and Drug Administration, reported three cases of swelling experienced by patients in areas previously injected with HA filler, introducing a possible relationship between the COVID-19 vaccine and adverse events (AE) in areas previously injected with HA filler [20]. These reports raised some concerns regarding their possible relationship among physicians involved in non-surgical facial aesthetic treatments. During our practice, we encountered a possible vaccine AE characterized by facial swelling following an HA filler injection. While several studies reported a correlation between orofacial swelling and COVID-19 vaccinations, the causal link is still unclear [21,22]. Therefore, a research study was developed that aimed to clarify this matter. A scoping review of the literature was chosen due to the lack of evidence, in order to clarify the incidence, any predisposing factors and to set a common ground for further research.

\section{Materials and Methods}

\subsection{Eligibility Criteria}

The methods and the inclusion criteria of the scoping review were set according to the quality standards described in the PRISMA 2020 checklist [23]. Every study that documented patients experiencing facial filler complications following the administration of a COVID-19 vaccine was included.

\subsection{Information Sources}

The research was carried out on the electronic databases PubMed, Cochrane Library, Web of Science, Google Scholar and Scopus. All articles related to the topic were identified. The search was concluded on 17 August 2021. No article language restriction was applied.

\subsection{Search Strategy}

The keywords were used and combined with Boolean operators, adapted for every database, both as text words and Medical Search Headings (MeSH terms). The keywords used were the following: COVID-19 vaccines AND fillers.

\subsection{Article and Data Selection Process}

The full texts of all studies documenting facial filler AE following a COVID-19 vaccine were included, with no study design restrictions. Articles were excluded if they did not report any clinical case or time-lapse between the COVID-19 vaccine and the AE. The reference lists of all the articles were examined to identify other potentially pertinent studies (Figure 1). 


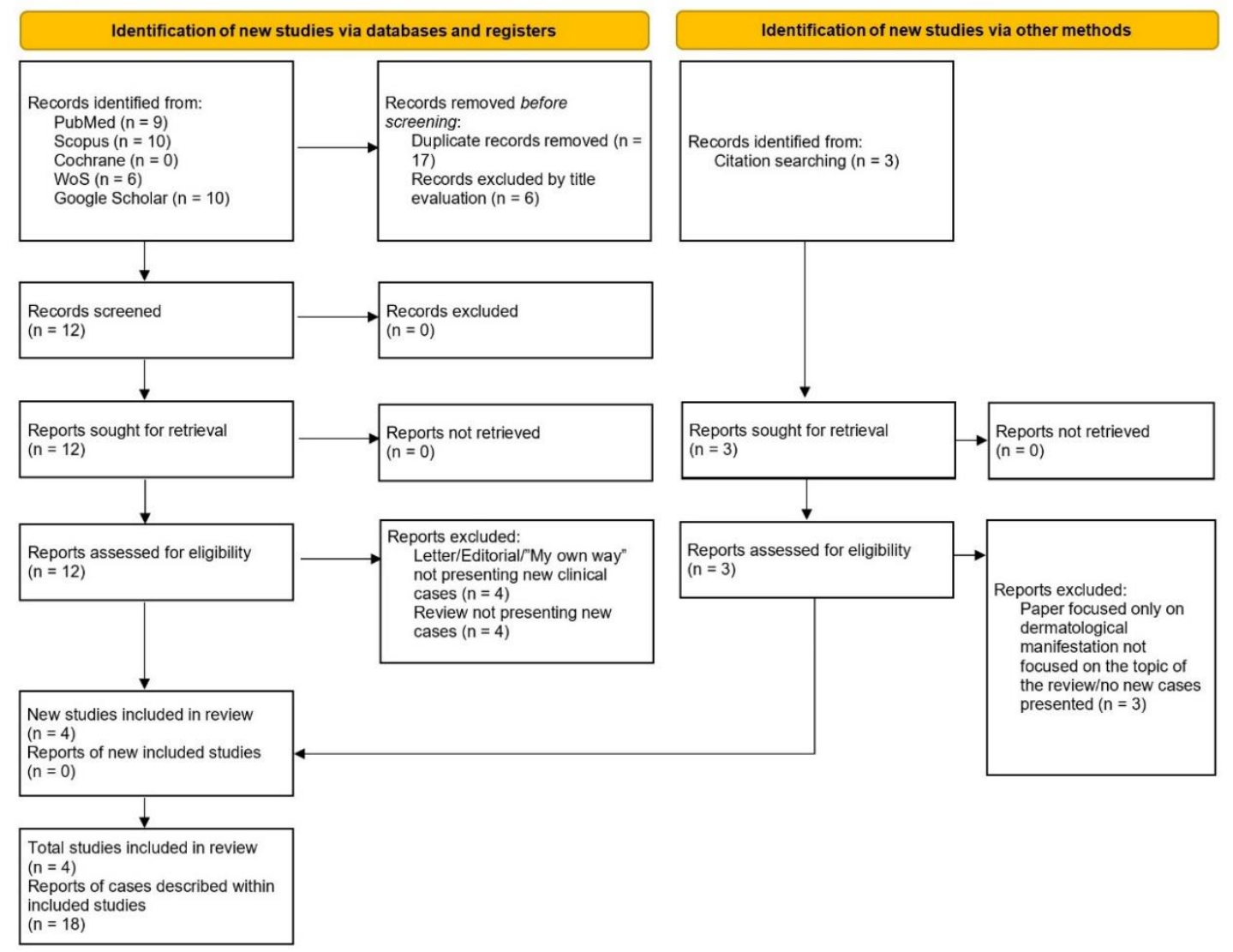

Figure 1. Study selection flow-chart.Two reviewers (R.F., N.Z.) independently performed eligibility assessment and data extraction. Disagreements between reviewers were resolved by consensus. When consensus was not reached, a senior member mediated (R.R.). A standard chart form of the obtained data was prepared to facilitate comparison of the articles.

\subsection{Data Items}

The following data were extracted from each study: author, patient's gender and age, filler injected and anatomical site of injections, date of filler injection, time-lapse between COVID-19 vaccine and clinical manifestation of $\mathrm{AE}$, the type of diverse event occurred, the treatment performed and the outcome (Table 1).

\subsection{Case Report}

In June 2021, a 44 year old caucasian patient, who was physically fit and healthy, developed a right lower eyelid edema along with ipsilateral conjunctivitis (Figure 2A) one week following a second dose of the mRNA Pfizer-BioNTech COVID-19 vaccine (8 June 2021). 
Table 1. Review results. Patients' demographics.

\begin{tabular}{|c|c|c|c|c|c|c|c|c|}
\hline Author & $\begin{array}{l}\text { Patient Features } \\
\text { (Gender; Age) }\end{array}$ & Medical Status & $\begin{array}{c}\text { Filler } \\
\text { Injected/Anatomical } \\
\text { Site }\end{array}$ & Injection Date & $\begin{array}{c}\text { Time-Lapse } \\
\text { between COVID-19 } \\
\text { Vaccine and } \\
\text { Adverse Event }\end{array}$ & Adverse Event & $\begin{array}{l}\text { Treatment } \\
\text { Performed }\end{array}$ & Outcome \\
\hline Michon A. [24] & $\mathrm{F} ; 39$ & $\begin{array}{l}\text { Physically fit and } \\
\text { healthy, and without } \\
\text { any medical } \\
\text { comorbidities } \\
\text { nor allergies. }\end{array}$ & $\begin{array}{l}\text { Juvéderm Volite } \\
\text { (Allergan, Irvine } \\
\text { CA)/tear trough }\end{array}$ & October 2020 & $\begin{array}{l}2 \text { days after the 1st } \\
\text { dose of mRNA } \\
\text { Pfizer-BioNTech } \\
\text { COVID-19 vaccine } \\
\text { (April 2021) }\end{array}$ & $\begin{array}{c}\text { Tender, } \\
\text { erythematous } \\
\text { swelling at the left } \\
\text { tear trough area }\end{array}$ & Watch-and-wait. & Resolution \\
\hline Michon A. [24] & $\mathrm{F} ; 61$ & $\begin{array}{l}\text { Physically healthy, } \\
\text { without allergies or } \\
\text { significant medical } \\
\text { history, except for } \\
\text { intermittent } \\
\text { benign vertigo. }\end{array}$ & $\begin{array}{c}\text { Juvéderm Voluma; } \\
\text { Juvederm Volux; } \\
\text { Juvéderm Volift; } \\
\text { Juvederm Volbella } \\
\text { (Allergan, Irvine } \\
\text { CA)/Pan facial injections }\end{array}$ & June 2020 & $\begin{array}{l}\text { A few days after the } \\
\text { 1st dose of mRNA } \\
\text { Pfizer-BioNTech } \\
\text { COVID-19 vaccine } \\
\text { (April 2021) }\end{array}$ & $\begin{array}{l}\text { Intermittent facial } \\
\text { swelling on either } \\
\text { side of the face, } \\
\text { localized primarily } \\
\text { at the cheeks } \\
\text { and undereye }\end{array}$ & $\begin{array}{l}\text { Hyaluronidase } \\
\text { injections }\end{array}$ & Resolution \\
\hline McMahon et al. [25] & $\begin{array}{l}3 \text { patients (gender } \\
\text { and age N.S.) }\end{array}$ & N.S. & N.S. & N.S. & $\begin{array}{l}\text { After the 1st dose of } \\
\text { mRNA Moderna } \\
\text { COVID-19 vaccine }\end{array}$ & $\begin{array}{l}\text { Swelling at the site } \\
\text { of cosmetic } \\
\text { filler injection }\end{array}$ & N.S. & N.S. \\
\hline McMahon et al. [25] & $\begin{array}{l}5 \text { patients (gender } \\
\text { and N.S.) }\end{array}$ & N.S. & N.S. & N.S. & $\begin{array}{l}\text { After the } 2 \text { st dose of } \\
\text { mRNA Moderna } \\
\text { COVID-19 vaccine }\end{array}$ & $\begin{array}{l}\text { Swelling at the site } \\
\text { of cosmetic filler } \\
\text { injection }\end{array}$ & N.S. & N.S. \\
\hline McMahon et al. [25] & $\begin{array}{l}1 \text { patient (gender } \\
\text { and N.S.) }\end{array}$ & N.S. & N.S. & N.S. & $\begin{array}{c}\text { After the 2st dose of } \\
\text { mRNA } \\
\text { Pfizer-BioNTech } \\
\text { COVID-19 vaccine }\end{array}$ & $\begin{array}{l}\text { Swelling at the site } \\
\text { of cosmetic } \\
\text { filler injection }\end{array}$ & N.S. & N.S. \\
\hline Munavalli et al. [26] & $\mathrm{F} ; 36$ & Healthy & $\begin{array}{l}\text { Juvederm. Voluma } \\
\text { (Allergan, Irvine } \\
\text { CA)/tear troughs. } \\
\text { Juvederm. Ultra } \\
\text { (Allergan, Irvine } \\
\text { CA)/upper and lower lip }\end{array}$ & November 2019 & $\begin{array}{l}24 / 48 \mathrm{~h} \text { following } \\
\text { the } 1 \text { st dose of } \\
\text { mRNA Moderna } \\
\text { COVID-19 vaccine } \\
\text { (5 January 2020) }\end{array}$ & $\begin{array}{c}\text { Unilateral } \\
\text { infraorbital edema } \\
\text { and perioral edema }\end{array}$ & $\begin{array}{l}\text { Early certirizine } \\
\text { administration } \\
\text { (twice); due to } \\
\text { worsening Lisinopril } \\
\text { was administrated. }\end{array}$ & Resolution \\
\hline
\end{tabular}


Table 1. Cont.

\begin{tabular}{|c|c|c|c|c|c|c|c|c|}
\hline Author & $\begin{array}{l}\text { Patient Features } \\
\text { (Gender; Age) }\end{array}$ & Medical Status & $\begin{array}{c}\text { Filler } \\
\text { Injected/Anatomical } \\
\text { Site }\end{array}$ & Injection Date & $\begin{array}{c}\text { Time-Lapse } \\
\text { between COVID-19 } \\
\text { Vaccine and } \\
\text { Adverse Event }\end{array}$ & Adverse Event & $\begin{array}{l}\text { Treatment } \\
\text { Performed }\end{array}$ & Outcome \\
\hline Munavalli et al. [26] & $\mathrm{F} ; 43$ & Healthy & $\begin{array}{l}\text { Juvederm Voluma } \\
\text { (Allergan, Irvine } \\
\text { CA)/lateral parts of } \\
\text { her cheeks. }\end{array}$ & 2.5 years before & $\begin{array}{l}24 \mathrm{~h} \text { following the } \\
\text { 2nd dose of mRNA } \\
\text { Pfizer-BioNTech } \\
\text { COVID-19 vaccine } \\
\text { (7 January 2021) }\end{array}$ & $\begin{array}{l}\text { Swelling in } \\
\text { periorbital area }\end{array}$ & $\begin{array}{c}\text { Medrol } \\
\text { administration; } \\
\text { linisopril } \\
\text { administration } \\
\text { reported on the } \\
\text { second paper (JAAD } \\
\text { Case Reports } \\
\text { 2021;10:63-8.) }\end{array}$ & Resolution \\
\hline Munavalli et al. [27] & $\mathrm{F} ; 76$ & Healthy & $\begin{array}{c}\text { Juvederm Ultra } \\
\text { (Allergan, Irvine } \\
\text { CA)/cheeks }\end{array}$ & 2019 & $\begin{array}{l}\text { Ten days after the } \\
\text { first dose of mRNA } \\
\text { Pfizer-BioNTech } \\
\text { COVID-19 Vaccine } \\
\text { (date not reported) }\end{array}$ & $\begin{array}{c}\text { Panfacial and } \\
\text { periorbital swelling }\end{array}$ & $\begin{array}{c}\text { Linisopril } \\
\text { administration }\end{array}$ & Resolution \\
\hline Munavalli et al. [27] & $\mathrm{F} ; 31$ & $\begin{array}{l}\text { No known drug } \\
\text { allergies and no } \\
\text { history of } \\
\text { angioedema }\end{array}$ & $\begin{array}{l}\text { Juvederm Volbella } \\
\text { (Allergan, Irvine } \\
\text { CA)/Lips. Juvederm } \\
\text { Voluma (Allergan, Irvine } \\
\text { CA)/Earlobes. Juvederm } \\
\text { Ultra (Allergan, Irvine } \\
\text { CA)/Nasolabial folds. } \\
\text { Juvederm Voluma } \\
\text { (Allergan, Irvine } \\
\text { CA)/malar cheeks }\end{array}$ & $\begin{array}{c}\text { Fall 2018, October } \\
\text { 2018, June } 2019 \text { and } \\
\text { June } 2020\end{array}$ & $\begin{array}{l}\text { Twenty-four hours } \\
\text { after the second dose } \\
\text { of mRNA Moderna } \\
\text { COVID-19 vaccine } \\
\text { (January/ } \\
\text { February 2021) }\end{array}$ & $\begin{array}{l}\text { Swelling of the } \\
\text { upper mucosal lip, } \\
\text { which progressed to } \\
\text { involve the left } \\
\text { earlobe and } \\
\text { bilateral zygomas }\end{array}$ & $\begin{array}{c}\text { Linisopril } \\
\text { administration }\end{array}$ & Resolution \\
\hline $\begin{array}{l}\text { Moderna Clinical } \\
\text { Trial [20] }\end{array}$ & $\mathrm{F} ; 46$ & Healthy & $\begin{array}{l}\text { Juvederm XC (Allergan, } \\
\text { Irvine CA)/Cheeks }\end{array}$ & March 2020 & $\begin{array}{l}\text { Within } 7 \text { days from } \\
\text { the 2nd dose of } \\
\text { mRNA Moderna } \\
\text { COVID-19 vaccine } \\
\text { (29 September 2020) }\end{array}$ & $\begin{array}{l}\text { Significant bilateral } \\
\text { cheek swelling }\end{array}$ & $\begin{array}{l}\text { Diphenhydramine } \\
\text { and } \\
\text { methylprednisolone } \\
\text { administration }\end{array}$ & Resolution \\
\hline
\end{tabular}


Table 1. Cont

\begin{tabular}{|c|c|c|c|c|c|c|c|c|}
\hline Author & $\begin{array}{l}\text { Patient Features } \\
\text { (Gender; Age) }\end{array}$ & Medical Status & $\begin{array}{c}\text { Filler } \\
\text { Injected/Anatomical } \\
\text { Site }\end{array}$ & Injection Date & $\begin{array}{c}\text { Time-Lapse } \\
\text { between COVID-19 } \\
\text { Vaccine and } \\
\text { Adverse Event }\end{array}$ & Adverse Event & $\begin{array}{l}\text { Treatment } \\
\text { Performed }\end{array}$ & Outcome \\
\hline $\begin{array}{l}\text { Moderna Clinical } \\
\text { Trial [20] }\end{array}$ & $\mathrm{F} ; 51$ & Healthy & $\begin{array}{l}\text { Juvederm XC (Allergan, } \\
\text { Irvine CA)/Cheeks }\end{array}$ & October 2020 & $\begin{array}{l}\text { Within } 7 \text { days from } \\
\text { the 2nd dose of } \\
\text { mRNA Moderna } \\
\text { COVID-19 vaccine } \\
\text { (15 October 2020) }\end{array}$ & $\begin{array}{l}\text { Bilateral facial } \\
\text { swelling }\end{array}$ & $\begin{array}{l}\text { Prednisolone } \\
\text { administration }\end{array}$ & Resolution \\
\hline $\begin{array}{l}\text { Moderna Clinical } \\
\text { Trial [20] }\end{array}$ & F; 29 & $\begin{array}{l}\text { The patient reported } \\
\text { the same lip } \\
\text { angioedema after } \\
\text { receipt of an } \\
\text { influenza vaccine in } \\
\text { the past. }\end{array}$ & N.S./lips & $\begin{array}{l}\text { unknown how long } \\
\text { prior to vaccination }\end{array}$ & $\begin{array}{l}2 \text { days after vaccine } \\
\text { injection (date not } \\
\text { reported) }\end{array}$ & Lip angioedema & N.S. & $\begin{array}{l}\text { It is assumed to } \\
\text { be solved }\end{array}$ \\
\hline $\begin{array}{c}\text { Rauso et al. } \\
\text { (unpublished data) }\end{array}$ & $\mathrm{F} ; 44$ & $\begin{array}{c}\text { Healthy. Tardive } \\
\text { lower eyelid } \\
\text { swelling already } \\
\text { experienced } \\
\text { following Juv ederm } \\
\text { Volbella (Allergan), } \\
\text { solved following } \\
3 \text { session of } \\
\text { hyyluronidase injections }\end{array}$ & $\begin{array}{l}\text { Redensity II (Teoxane; } \\
\text { Geneve, Swiss)/tear } \\
\text { trough } \\
\text { s }\end{array}$ & January 2020 & $\begin{array}{l}\text { Seven days after the } \\
\text { second dose of } \\
\text { mRNA } \\
\text { Pfizer-BioNTech } \\
\text { COVID-19 vaccine (8 } \\
\text { June 2021) }\end{array}$ & $\begin{array}{l}\text { Right lower eyelid } \\
\text { swelling and } \\
\text { ipsilateral } \\
\text { conjunctivitis }\end{array}$ & Watch-and-wait & Resolution \\
\hline
\end{tabular}




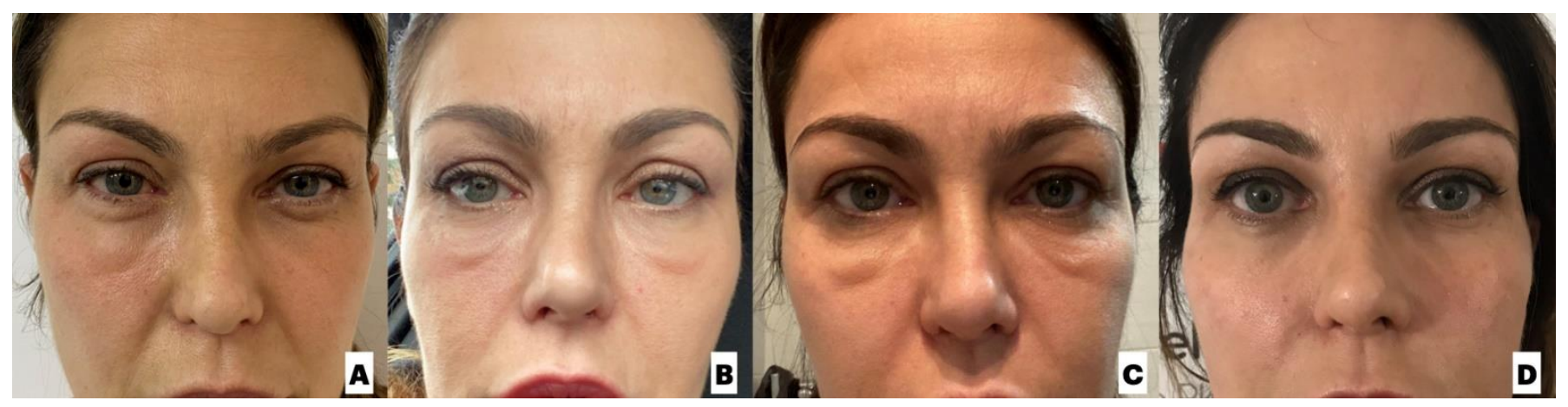

Figure 2. (A) A 44 year old lady experiencing a right lower eyelid edema with ipsilateral conjunctivitis, 1 week after the second dose of mRNA Pfizer-BioNTech COVID-19 vaccine; (B) The same patient experiencing bilateral lower eyelid edema approximately 1 year following Juvederm Volbella (Allergan, Irvine CA) injections; (C) Clinical appearance of the patient three weeks following a second session of hyaluronidase injections; (D) Resolution of late-onset tear trough edema following three sessions of hyaluronidase.

The medical history of the patient revealed that multiple facial filler injections had been performed on her lips, malar, naso-labial fold, chin and temple areas. The patient reported injections with both HA (using different brands over the years) and calcium hydroxyapatite from 2012 to 2020: during this time-lapse, AE were reported.

In May 2013, lip angioedema was recorded following an HA lip filler (Belotero Balance, Merz Pharma, Italia). This was resolved after three days of oral corticosteroid (betamethasone) therapy.

At the end of 2017 the patient received tear trough deformity treatment for the first time, using Juvederm Volbella (Allergan, Irvine, CA, USA). In October 2018, she developed bilateral lower eyelid edema (Figure 2B). A medical examination bilaterally revealed a swollen, mildly erythematous and tender tear trough area; the patient was prescribed an oral administration of betamethasone ( $1 \mathrm{mg}$ per day for three days) and cetirizine dihydrochloride ( $10 \mathrm{mg}$ per day for three days). Following the medical therapy, no improvement was recorded and the patient was admitted for hyaluronidase injections. Three sessions of hyaluronidase injections were performed (300 units per side, per session). The first and second sessions were spaced by three weeks (Figure 2C), the last one was performed forty days after the second (Figure 2D). Between the second and the third session, the patient also experienced bilateral conjunctivitis that self-resolved within five days.

In January 2020, the patient was bilaterally treated with Redensity II (Teoxane, Geneve, Switzerland) in the tear trough area, and AE were not recorded up to the second COVID-19 vaccine injection. One week after the second dose of the COVID-19 vaccine, the patient experienced right tear trough swelling along with ipsilateral conjunctivitis, and a watchand-wait approach was taken. The AE spontaneously resolved by day seven, without any intervention.

\section{Results}

\section{Study Selection and Characteristics}

The PubMed, Web of Science, Google Scholar, Cochrane Library and Scopus database searches identified 35 articles: 17 were duplicate articles, 3 more articles were identified by reference lists of all examined articles. Twenty-one studies were screened for title; six were excluded by title evaluation. Fifteen full-text articles were finally selected for full-text evaluation. Of the 15 fully evaluated papers, 11 were excluded: 3 because they did not report cases related to facial filler adverse events; 4 letters/editorials because no clinical cases were reported; 4 reviews were excluded because clinical cases already present in the other papers were described. 
The selection process identified four pieces of research eligible for inclusion in the review: Michon A. (2021) [24]; McMahon et al. (2021) [25]; Munavalli et al. (2021) [26]; Munavalli et al. (2021) [27]. A total of 18 patients were evaluated. (Figure 2).

\section{Discussion}

Delayed inflammatory reactions are usually defined as an AE recorded 2-4 weeks or longer after the administration of facial filler injections [28]. Dental procedures, improper injective techniques or low-quality products are just a few of the many triggers that have been suggested to lead to this phenomenon [28].

In 2011, Shoenfeld and Agmon-Levin coined the term autoimmune/inflammatory syndrome induced by adjuvants (ASIA) to identify several clinical and laboratory features related to the exposure to different external stimuli, such as bacteria, viruses, vaccines, etc. [29]. In 2018, Alijotas-Reig et al. reported a possible relationship between the medical use of implants and delayed inflammatory disorders in 45 consecutive patients: only cases with at least a three month symptom-free span between the filler injection and clinical onset were included, although the interval exceeded 12 months in the majority of cases [30].

On 17 December 2020, the FDA issued the Emergency Use Authorizations for Pfizer/ BioNTech (BNT162b2) and Moderna (mRNA-1273) COVID-19 vaccines. Clinical trials for both vaccines reported site reactions and systemic symptoms after both doses; the Moderna vaccine additionally showed three cases of facial swelling after cosmetic filler injections [20].

Since the Emergency Use Authorization was issued by the FDA, concern began to emerge regarding the use of facial filler. Empirically, some scientific societies recommended the avoidance of facial filler administration before the first dose of the vaccine, during the time-lapse between the two doses and for at least one month following the last dose of the vaccine [31]. On the other hand, few cases reporting swelling in sites previously injected sites were described, and different suggestions were given: e.g., Michon suggested waiting at least three weeks after the COVID-19 vaccine before facial filler injections in order to reduce the possibility of $\mathrm{AE}$ [24].

In this research, we performed a scoping review to identify every case of $\mathrm{AE}$ recorded following the first or second dose of a COVID-19 vaccine and collected all available clinical data. During the review process, some limitations arose [24-27].

McMahon et al., in a registry-based study of 414 cases, described a larger number of patients (nine) who experienced swelling at the site of cosmetic filler injections, although the authors did not report detailed information regarding patients' gender, their medical status, the type of filler used, the area injected, the treatment performed or the outcome [25].

Some issues were also identified during the review process, while evaluating the two papers published by Munavalli et al. [26,27]. In the first research paper, released in February 2021 [26], four patients were studied, with one patient developing swelling in an area previously injected with filler following actual COVID-19 infection, not following the vaccine. One patient involved in the Moderna clinical trial experienced several facial adverse events. However, before article publication, the patient was notified that they had been injected with the saline placebo. Notably, at the end of this study, the adverse event developed by this second patient, which was characterized by persistent swelling after medical treatments and several hyaluronidase injections, was not solved. In the last two presented clinical cases, both developed periorbital/infraorbital swelling following the vaccine and fully recovered following medical treatment. The second research paper released by Munavalli et al. [27] was focused on the use of linisopril for facial swelling in areas previously injected by filler, following a COVID-19 vaccine. Two of these cases were already published in the previous paper, and were identified by the same patient pictures being published. Confusion emerged around patient identification as "case 3 " in both papers (with the same pictures in both papers) described the same person, although a different therapeutic approach was reported: in the first paper, Medrol administration 
solved the case; in the second paper, Medrol was not mentioned and only linisopril administration was reported as a medical treatment.

Michon was the only one who clearly reported two cases of patients experiencing swelling following vaccine administration: in one case, a watch-and-wait approach was resolutive, with no medication, and in the other one, a hyaluronidase injection solved the case [24].

Three more cases were described during the Moderna clinical trial [20], although only data regarding the first two patients were clear: patients received an injection of fillers into the cheeks and developed facial swelling following a COVID-19 vaccine. The last case described in the Moderna clinical trial was characterized by lip angioedema following a vaccine injection, although it was not known how long prior to vaccination the lip implant was injected or what kind of filler was injected (i.e., was it permanent?). The medical history of the patient also revealed the same lip angioedema after recieving an influenza vaccine in the past [20].

If we take account for the high number of patients who received dermal filler injections in recent years and the high number of patients vaccinated since vaccine development, 19 cases of AE (15 from published research, 3 cases during the Modenal clinical trial and the case reported in this work) would seem to suggest a really low rate of incidence. Notably, facial AE were only described following Moderna and Pfizer vaccinations.

Following COVID-19 vaccine administration, allergic and anaphylactic reactions have been reported and several hypothesis have emerged [32,33]. Garvey and Nasser suspected that polyethylene glycol (PEG), an inactive ingredient in the vaccine preparation, was involved with these AE [34]. PEG is widely used and is present in laxatives, makeup, chemotherapy drugs, etc. [35]. Moreover, HA fillers cross-linked with PEG, instead of 1,4-butanediol diglycidyl ether (BDDE), are commercially available [36,37]. To date, no AE were recorded in this class of fillers, showing a high biocompatibility and safety profile from an immunological perspective $[38,39]$.

Based on the available published data, facial AE in areas previously injected with filler were recorded 5 times following the first dose of Moderna vaccine, 8 times following the second dose of the same vaccine, 3 times after the administration of the first Pfizer vaccine dose and 3 times following the second dose of the same vaccine.

Data regarding $\mathrm{AE}$ treatments and the outcomes were available for only nine patients. In 6 cases, medical therapy was administrated, in 2 cases a watch-and-wait approach was employed, and in 1 case, a hyaluronidase injection was utilized. Every AE described for the patients were resolved.

Concerning our report, the patient had a long history of different facial filler injections, from 2012 to 2020. During this long time-lapse, two adverse events were recorded: a lip angioedema in 2013 using a Belotero product and a tardive bilateral swelling about 10 months after receiving Volbella (Allergan, Irvine CA) injections in the tear trough area. Lip angioedema was resolved with medical therapy, whereas tear trough swelling was unresponsive to medical approaches. To solve the latter $\mathrm{AE}$, three sessions of hyaluronidase injections were administered. Although the patient was re-injected with another brand of filler, following the second dose of a COVID-19 vaccine, she developed swelling in the right lower eyelid, which self-resolved within a few days. Due to the great resistance to hayluronidase injection evidenced in this case, the persistence of Volbella (Allergan, Irvine CA) cannot be excluded.

Data regarding the type of filler previously injected were available in only 9 out of 19 patients. Notably, of those 9 patients, 8 received Allergan fillers (Vycross or Hylacross technology), and the last one, described in the present paper, also had a history of tardive swelling following Allergan filler injections.

Hylacross and Vycross are two different HA technologies developed by Allergan (Irvine, CA, USA); the former is characterized by a higher cross-linking rate of BDDE, ranging from $9 \%$ to $11 \%$, to achieve a more viscous and long-lasting filler, while the latter 
is characterized by a mixture of low- and high-molecular-weight HA to achieve a smoother and long-lasting filler.

BDDE could be a potential source for the late-onset of inflammatory reactions: the degradation of cross-linked HA filler may expose traces of BDDE, and the gradual exposure or release of these molecules could trigger the immune system [40,41]. This could explain the late-onset AE related to the use of Hylacross technology.

On the other hand, some concerns related to tardive AE, such as swelling following Vycross technology, have already arisen in the medical literature [28,39,42]. Sadeghpour et al. (2019) described their experience with Juvederm Vycross fillers and concluded that the introduction of this new class of filler introduced a new variable that may change the immune tolerance of these substances, resulting in a higher incidence of delayed adverse events than previously expected [42].

In 2017, Niforos et al. evaluated the effectiveness and safety of Juvederm Volbella (Allergan, Irvine, CA, USA), belonging to the "Vycross family", for the correction of infraorbital skin depression (tear trough) in 80 patients. Following the investigators' assessment, some AE were not detectable until six months after the injections. Late-onset, mild-to-moderate edema was detected in $11 \%$ of cases at 6 months, $5 \%$ at 9 months, and $4 \%$ at 12 months [43]. A few more pieces of research investigated the link between Juvederm Volbella (Allergan, Irvine, CA,USA) and delayed complications, revealing an incidence rate ranging from $0.3 \%$ to $4.25 \%$.

The exact mechanism implicated in delayed AE such as tardive swelling is not completely clear, although it has been postulated that an immunological trigger can be detected [44-47]. Turkmani et al. described a case series based on fourteen patients with a history of soft tissue filler injections having experienced tardive AE after the beginning of a flu-like illness [48].

Vycross technology, introduced by Allergan, moved from the 100\% high-molecularweight (HMW) HA filler to a 10\% HMW and a 90\% low-molecular-weight (LMW) HA filler [47,49]. HMW HA is known to have an anti-inflammatory effect; on the other hand, it has shown that LMW HA, less than $20 \mathrm{kDa}$, has a pro-inflammatory effect [50,51]. Beleznay et al. suggested that systemic inflammatory responses, such as flu-like illnesses or vaccines, accelerate LMW HA degradation from acute free radical production influencing CD44-HA, signaling and resulting in delayed adverse events [44].

In February 2021, the Cosmetic Surgery Forum (CSF) discussed the risk of delayed facial swelling in filler patients following COVID-19 vaccination [52]. Doris Day, a New York City dermatologist and CSF panelist, stated that, regarding the type of filler that most likely caused tardive reaction following the administration of a COVID-19 vaccine, data were trending more toward Vycross fillers [52].

\section{Conclusions}

From the present scoping review, considering the high number of patients who have received COVID-19 vaccines over the last year, and also considering the high number of patients who have received facial filler injections in recent years, AE following Moderna and Pfizer vaccines were detected in a very limited number. Every patient showing AE following a COVID-19 vaccine was previously injected with fillers manufactured by Allergan (Irvine, CA). This outcome seems to support the previously published medical literature, linking the reported AE to the high BDDE cross-linking rate and/or LMW HA filler rather than to the COVID-19 vaccine. These type of fillers may have a higher tardive $\mathrm{AE}$ rate when triggered.

Author Contributions: Conceptualization, R.R.; methodology, N.Z.; formal analysis, R.F.; data curation, G.F.N.; writing—original draft preparation, R.R.; writing—review and editing, G.L.G.; supervision, G.T. All authors have read and agreed to the published version of the manuscript.

Funding: This research received no external funding. 
Institutional Review Board Statement: The study was conducted according to the guidelines of the Declaration of Helsinki. Every patient provided informed consent for the procedures, the use and publication of images and clinical data for scientific research purposes and signed a consent form. Data privacy was handled according GDPR.

Informed Consent Statement: Informed consent was obtained from all subjects involved in the study.

Data Availability Statement: Data are available upon request.

Conflicts of Interest: The authors declare no conflict of interest.

$\begin{array}{ll}\text { Abbreviations } \\ \text { AE } & \text { Adverse events } \\ \text { ASAPS } & \text { American Society of Aesthetic Plastic Surgery } \\ \text { ASIA } & \text { Autoimmune/inflammatory Syndrome Induced by Adjuvants } \\ \text { BDDE } & \text { 1,4-butanediol diglycidyl ether } \\ \text { COVID-19 } & \text { Coronavirus Disease 19 } \\ \text { CSF } & \text { Cosmetic Surgery Forum } \\ \text { FDA } & \text { Food and Drugs Administration } \\ \text { HA } & \text { Hyaluronic Acid } \\ \text { HMW } & \text { High Molecular Weight } \\ \text { ICU } & \text { Intensive Care Unit } \\ \text { LMW } & \text { Low Molecular Weight } \\ \text { PEG } & \text { Polyethylene glycol } \\ \text { WHO } & \text { World Health Organization }\end{array}$

\section{References}

1. Ghebreyesus, T.A. WHO Director-General's Opening Remarks at the Media Briefing on COVID-19 11 March 2020. Available online: https: / / www.who.int/director-general/speeches/detail/who-director-general-s-opening-remarks-at-the-mediabriefing-on-covid-19-11-march-2020 (accessed on 27 September 2021).

2. Kaye, K.; Paprottka, F.; Escudero, R.; Casabona, G.; Montes, J.; Fakin, R.; Moke, L.; Stasch, T.; Richter, D.; Benito-Ruiz, J. Elective, Non-urgent Procedures and Aesthetic Surgery in the Wake of SARS-COVID-19: Considerations Regarding Safety, Feasibility and Impact on Clinical Management. Aesthetic. Plast Surg. 2020, 44, 1014-1042. [CrossRef] [PubMed]

3. Soreide, K.; Hallet, J.; Matthews, J.B.; Schnitzbauer, A.A.; Line, P.D.; Lai, P.B.S.; Otero, J.; Callegaro, D.; Warner, S.G.; Baxter, N.N.; et al. Immediate and long-term impact of the COVID-19 pandemic on delivery of surgical services. Br. J. Surg. 2020, 107, 1250-1261. [CrossRef]

4. Rauso, R.; Chirico, F.; Federico, F.; Francesco Nicoletti, G.; Colella, G.; Fragola, R.; Pafundi, P.C.; Tartaro, G. Maxillo-facial reconstruction following cancer ablation during COVID-19 pandemic in southern Italy. Oral Oncol. 2021, 115, 105114. [CrossRef] [PubMed]

5. Koscielecka, K.E.; Kuc, A.J.; Kubik, D.M.; Mecik-Kronenberg, T.; Ceglarz, D. Impact of the Covid-19 Pandemic on the Availability of Medical Care among Oncological Patients. Wiad. Lek. 2021, 74, 1542-1551. [CrossRef] [PubMed]

6. Shanbehzadeh, M.; Kazemi-Arpanahi, H.; Kalkhajeh, S.G.; Basati, G. Systematic review on telemedicine platforms in lockdown periods: Lessons learned from the COVID-19 pandemic. J. Educ. Health Promot. 2021, 10, 211. [CrossRef] [PubMed]

7. Adejumo, O.A.; Adejumo, O.A. Prospects of telemedicine during and post COVID-19: Highlighting the environmental health implications. Malawi Med. J. 2020, 32, 235-238. [CrossRef]

8. Kim, H.; Lee, H.; Park, C.S.; Kim, S.; Cho, S.A.; Yoo, S.M.; Kim, J.A.; Lee, J.Y. Preliminary Results of Teleconsultations Temporarily Allowed during the COVID-19 Pandemic. Yonsei Med. J. 2021, 62, 850-857. [CrossRef]

9. Lo Giudice, G.; Caterino, M.; Rauso, R.; Colella, G. The Multidisciplinary Approach in Head and Neck Oncology during COVID-19 Pandemic. J. Craniofac Surg 2021, 32, e835. [CrossRef]

10. Iqbal, M. Zoom Revenue and Usage Statistics (2021). Available online: https:/ /www.businessofapps.com/data/zoom-statistics/ (accessed on 27 September 2021).

11. The Aesthetic Society. Aesthetic Plastic Surgery National Databank Statistics 2019. Available online: https://www.surgery.org/ sites/default/files/Aesthetic-Society_Stats2019Book_FINAL.pdf (accessed on 27 September 2021).

12. The Aesthetic Society. Aesthetic Plastic Surgery National Databank Statistics 2020. Available online: https:/ / cdn.theaestheticsociety. $\mathrm{org} / \mathrm{media} /$ statistics/aestheticplasticsurgerynationaldatabank-2020stats.pdf (accessed on 27 September 2021).

13. Pfund, G.N.; Hill, P.L.; Harriger, J. Video chatting and appearance satisfaction during COVID-19: Appearance comparisons and self-objectification as moderators. Int. J. Eat. Disord. 2020, 53, 2038-2043. [CrossRef]

14. Chen, J.; Chow, A.; Fadavi, D.; Long, C.; Sun, A.H.; Cooney, C.M.; Broderick, K.P. The Zoom Boom: How Video Calling Impacts Attitudes towards Aesthetic Surgery in the COVID-19 Era. Aesthet Surg. J. 2021, 41, NP2086-NP2093. [CrossRef] 
15. Rauso, R.; Tartaro, G.; Chirico, F.; Zerbinati, N.; Albani, G.; Rugge, L. Rhinofilling with hyaluronic acid thought as a cartilage graft. J. Craniomaxillofac. Surg. 2020, 48, 223-228. [CrossRef] [PubMed]

16. Rauso, R.; Federico, F.; Zerbinati, N.; De Cicco, D.; Nicoletti, G.F.; Tartaro, G. Hyaluronic Acid Injections to Correct Lips Deformity Following Surgical Removal of Permanent Implant. J. Craniofac. Surg. 2020, 31, e604-e606. [CrossRef] [PubMed]

17. Rauso, R.; Sesenna, E.; Fragola, R.; Zerbinati, N.; Nicoletti, G.F.; Tartaro, G. Skin Necrosis and Vision Loss or Impairment after Facial Filler Injection. J. Craniofac. Surg. 2020, 31, 2289-2293. [CrossRef] [PubMed]

18. Rauso, R.; Zerbinati, N.; Fragola, R.; Nicoletti, G.F.; Tartaro, G. Transvascular Hydrolysis of Hyaluronic Acid Filler with Hyaluronidase: An Ex Vivo Study. Derm. Surg. 2021, 47, 370-372. [CrossRef]

19. Rauso, R.; Zerbinati, N.; Franco, R.; Chirico, F.; Ronchi, A.; Sesenna, E.; Colella, G.; Tartaro, G. Cross-linked hyaluronic acid filler hydrolysis with hyaluronidase: Different settings to reproduce different clinical scenarios. Derm. Ther. 2020, 33, e13269. [CrossRef]

20. Vaccines and Related Biological Products Advisory Committee Meeting 17 December 2020. Available online: https://www.fda. gov/media/144434/download (accessed on 27 September 2021).

21. Cirillo, N. Reported orofacial adverse effects of COVID-19 vaccines: The knowns and the unknowns. J. Oral Pathol. Med. 2021, 50, 424-427. [CrossRef]

22. Riad, A.; Pokorna, A.; Attia, S.; Klugarova, J.; Koscik, M.; Klugar, M. Prevalence of COVID-19 Vaccine Side Effects among Healthcare Workers in the Czech Republic. J. Clin. Med. 2021, 10, 1428. [CrossRef]

23. Page, M.J.; McKenzie, J.E.; Bossuyt, P.M.; Boutron, I.; Hoffmann, T.C.; Mulrow, C.D.; Shamseer, L.; Tetzlaff, J.M.; Akl, E.A.; Brennan, S.E.; et al. The PRISMA 2020 statement: An updated guideline for reporting systematic reviews. BMJ 2021, 372, n71. [CrossRef]

24. Michon, A. Hyaluronic acid soft tissue filler delayed inflammatory reaction following COVID-19 vaccination-A case report. J. Cosmet. Derm. 2021, 20, 2684-2690. [CrossRef]

25. McMahon, D.E.; Amerson, E.; Rosenbach, M.; Lipoff, J.B.; Moustafa, D.; Tyagi, A.; Desai, S.R.; French, L.E.; Lim, H.W.; Thiers, B.H.; et al. Cutaneous reactions reported after Moderna and Pfizer COVID-19 vaccination: A registry-based study of 414 cases. J. Am. Acad. Derm. 2021, 85, 46-55. [CrossRef]

26. Munavalli, G.G.; Guthridge, R.; Knutsen-Larson, S.; Brodsky, A.; Matthew, E.; Landau, M. COVID-19/SARS-CoV-2 virus spike protein-related delayed inflammatory reaction to hyaluronic acid dermal fillers: A challenging clinical conundrum in diagnosis and treatment. Arch. Derm. Res. 2021. [CrossRef]

27. Munavalli, G.G.; Knutsen-Larson, S.; Lupo, M.P.; Geronemus, R.G. Oral angiotensin-converting enzyme inhibitors for treatment of delayed inflammatory reaction to dermal hyaluronic acid fillers following COVID-19 vaccination-a model for inhibition of angiotensin II-induced cutaneous inflammation. JAAD Case Rep. 2021, 10, 63-68. [CrossRef]

28. Artzi, O.; Cohen, J.L.; Dover, J.S.; Suwanchinda, A.; Pavicic, T.; Landau, M.; Goodman, G.J.; Ghannam, S.; Al Niaimi, F.; van Loghem, J.A.J.; et al. Delayed Inflammatory Reactions to Hyaluronic Acid Fillers: A Literature Review and Proposed Treatment Algorithm. Clin. Cosmet. Investig. Derm. 2020, 13, 371-378. [CrossRef] [PubMed]

29. Shoenfeld, Y.; Agmon-Levin, N. 'ASIA'-Autoimmune/inflammatory syndrome induced by adjuvants. J. Autoimmun. 2011, 36, 4-8. [CrossRef]

30. Alijotas-Reig, J.; Fernandez-Figueras, M.T.; Puig, L. Late-onset inflammatory adverse reactions related to soft tissue filler injections. Clin. Rev. Allergy Immunol. 2013, 45, 97-108. [CrossRef]

31. Vaccino COVID-19 Moderna \& Filler-Position Statement Ufficiale del Collegio Italiano delle Società Scientifiche di Medicina Estetica. Available online: https://www.lamedicinaestetica.it/wp-content/uploads/2021/01/POSITION-STATEMENT-VACCINOCOVID19-MODERNA-E-HA.pdf (accessed on 27 September 2021).

32. Freeman, E.E.; McMahon, D.E.; Lipoff, J.B.; Rosenbach, M.; Kovarik, C.; Desai, S.R.; Harp, J.; Takeshita, J.; French, L.E.; Lim, H.W.; et al. The spectrum of COVID-19-associated dermatologic manifestations: An international registry of 716 patients from 31 countries. J. Am. Acad. Derm. 2020, 83, 1118-1129. [CrossRef]

33. Rice, S.M.; Ferree, S.D.; Kourosh, A.S. Coronavirus Vaccine Considerations for the Aesthetic Patient. Facial Plast. Surg. Aesthet. Med. 2021, 23, 75-76. [CrossRef]

34. Garvey, L.H.; Nasser, S. Anaphylaxis to the first COVID-19 vaccine: Is polyethylene glycol (PEG) the culprit? Br. J. Anaesth. 2021, 126, e106-e108. [CrossRef]

35. Chen, B.M.; Cheng, T.L.; Roffler, S.R. Polyethylene Glycol Immunogenicity: Theoretical, Clinical, and Practical Aspects of Anti-Polyethylene Glycol Antibodies. ACS Nano 2021, 15, 14022-14048. [CrossRef] [PubMed]

36. Zerbinati, N.; Haddad, R.G.; Bader, A.; Rauso, R.; D’Este, E.; Cipolla, G.; Calligaro, A.; Gonzalez, P.; Salvatore, S.; Serafin, D. A new hyaluronic acid polymer in the augmentation and restoration of labia majora. J. Biol. Regul Homeost. Agents 2017, 31, 153-161.

37. Zerbinati, N.; Lotti, T.; Monticelli, D.; Rauso, R.; Gonzalez-Isaza, P.; D’Este, E.; Calligaro, A.; Sommatis, S.; Maccario, C.; Mocchi, R.; et al. In Vitro Evaluation of the Biosafety of Hyaluronic Acid PEG Cross-Linked with Micromolecules of Calcium Hydroxyapatite in Low Concentration. Open Access Maced. J Med. Sci. 2018, 6, 15-19. [CrossRef] [PubMed]

38. Zerbinati, N.; D’Este, E.; Farina, A.; Rauso, R.; Cherubino, M.; Calligaro, A. Morphological evidences following pegylated filler treatment in human skin. J. Biol. Regul. Homeost. Agents 2017, 31, 79-85. [PubMed] 
39. Humphrey, S.; Jones, D.H.; Carruthers, J.D.; Carruthers, A.; Beleznay, K.; Wesley, N.; Black, J.M.; Vanderveen, S.; Minokadeh, A. Retrospective review of delayed adverse events secondary to treatment with a smooth, cohesive 20-mg/mL hyaluronic acid filler in 4500 patients. J. Am. Acad. Derm. 2020, 83, 86-95. [CrossRef]

40. Kim, J.E.; Sykes, J.M. Hyaluronic acid fillers: History and overview. Facial. Plast. Surg. 2011, 27, 523-528. [CrossRef]

41. Decates, T.; Kadouch, J.; Velthuis, P.; Rustemeyer, T. Immediate nor Delayed Type Hypersensitivity Plays a Role in Late Inflammatory Reactions After Hyaluronic Acid Filler Injections. Clin. Cosmet. Investig. Derm. 2021, 14, 581-589. [CrossRef]

42. Sadeghpour, M.; Quatrano, N.A.; Bonati, L.M.; Arndt, K.A.; Dover, J.S.; Kaminer, M.S. Delayed-Onset Nodules to Differentially Crosslinked Hyaluronic Acids: Comparative Incidence and Risk Assessment. Derm. Surg. 2019, 45, 1085-1094. [CrossRef]

43. Niforos, F.; Acquilla, R.; Ogilvie, P.; Safa, M.; Signorini, M.; Creutz, L.; Kerson, G.; Silberberg, M. A Prospective, Open-Label Study of Hyaluronic Acid-Based Filler with Lidocaine (VYC-15L) Treatment for the Correction of Infraorbital Skin Depressions. Derm. Surg. 2017, 43, 1271-1280. [CrossRef] [PubMed]

44. Beleznay, K.; Carruthers, J.D.; Carruthers, A.; Mummert, M.E.; Humphrey, S. Delayed-onset nodules secondary to a smooth cohesive $20 \mathrm{mg} / \mathrm{mL}$ hyaluronic acid filler: Cause and management. Derm. Surg. 2015, 41, 929-939. [CrossRef]

45. Mikkilineni, R.; Wipf, A.; Farah, R.; Sadick, N. New Classification Schemata of Hypersensitivity Adverse Effects after Hyaluronic Acid Injections: Pathophysiology, Treatment Algorithm, and Prevention. Derm. Surg. 2020, 46, 1404-1409. [CrossRef]

46. Rowland-Warmann, M.J. Hypersensitivity reaction to Hyaluronic Acid Dermal filler following novel Coronavirus infection-A case report. J. Cosmet Derm. 2021, 20, 1557-1562. [CrossRef]

47. Artzi, O.; Loizides, C.; Verner, I.; Landau, M. Resistant and Recurrent Late Reaction to Hyaluronic Acid-Based Gel. Derm. Surg. 2016, 42, 31-37. [CrossRef] [PubMed]

48. Turkmani, M.G.; De Boulle, K.; Philipp-Dormston, W.G. Delayed hypersensitivity reaction to hyaluronic acid dermal filler following influenza-like illness. Clin. Cosmet. Investig. Derm. 2019, 12, 277-283. [CrossRef]

49. Goodman, G.J.; Swift, A.; Remington, B.K. Current Concepts in the Use of Voluma, Volift, and Volbella. Plast. Reconstr. Surg. 2015, 136, 139S-148S. [CrossRef] [PubMed]

50. Jiang, D.; Liang, J.; Noble, P.W. Hyaluronan as an immune regulator in human diseases. Physiol. Rev. 2011, 91, 221-264. [CrossRef] [PubMed]

51. Scheibner, K.A.; Lutz, M.A.; Boodoo, S.; Fenton, M.J.; Powell, J.D.; Horton, M.R. Hyaluronan fragments act as an endogenous danger signal by engaging TLR2. J. Immunol. 2006, 177, 1272-1281. [CrossRef]

52. Schlessinger, J. Update on COVID-19 Vaccines and Dermal Fillers. Available online: https:/ practicaldermatology.com/articles/ 2021-feb/update-on-covid-19-vaccines-and-dermal-fillers (accessed on 27 September 2021). 